\title{
Implementation of KPKU (Kriteria Performa Kinerja Unggul) Method to Increase The Company Performance at PT. XYZ
}

\author{
Siswanto, Singgih Saptadi, and Arfan Bakhtiar \\ Department of Management and Industrial Engineering, Universitas Diponegoro, Semarang \\ e-mail: syswanto2002@yahoo.com, singgihs@ft.undip.ac.id, arfanbakhtiar@gmail.com
}

\begin{abstract}
Abstrak-Gas and steam power plant (PLTGU) is a power plant that can operate very quickly from start-up to generate electric power as quick as fifteen minutes compared with steam power plant which takes eight hours. PLTGU can use gas fuel, HSD (High Speed Diesel), MFO (Marine Fuel Oil) as the operating fuel and so that can be said generating reliable and flexible because it can operate in two modes of cycle, open cycle and combine cycle. Power Plant performance sometimes does not match with what we expected, we need a strategy in order to achieve optimal performance. The problem is the generation performance decrease from its optimal condition due to the plant aging, operation and governance pattern. Power Plant XYZ has not achieved the expected performance from 2015 to 2018 which still below $95 \%$ averages out of expected target $95 \%$ to $100 \%$. In order to improve the performance this research is used KPKU (Kriteria Performa Kinerja Unggul) methods which adopted from the Malcolm Baldrige Criteria for Performance Excellent (MBCFPE). The purpose of this study is to boost the company's competitive advantage, improve performance on an ongoing basis, and to achieve the vision and mission and objectives of the company.
\end{abstract}

Keywords-PLTGU, KPKU, SWOT, Malcolm Baldrige, Performance.

\section{INTRODUCTION}

$\mathrm{C}$ OMMENCING of disruptive changes on 4.0 Industrial era has driven all the industry to make more competitive in any sector. Industry and services business are recognizing the importance of maintaining the life and growth, supported by the development of technology and good management control system. The main component of good management control system is the measurement of company performance to determine the performance of the company [1].

Baldrige Excellence Framework (BEF) and Kriteria Performa Kinerja Unggul (KPKU) is considered as a comprehensive strategic planning system which popular among managers and business owners [2]. BEF and KPKU is a management system that helps organizations define their goals and strategies based on the different characteristics within the organization [3].

Since introduced on 1987, Malcolm Baldrige Criteria for Performance Excellence (MBCFPE) has become interesting topics among the practitioner and academics. A wide variety of benefits, both financial and non-financial claimed as a result of the use of MBCFPE. BEF and KPKU could clarify and gain consensus about strategy, communicate the strategy throughout the organization, align departments and strategic objectives, linking strategic objectives with longterm targets and annual budgets, identify and align strategic initiatives, pursuing a strategy of periodic, systematic and obtain feedback to learn and improve strategies [4].

In KPKU there is KPI (Key Performance Indicator) as a performance measurement indicator for each perspective of the Balanced Scorecard [3][4]. But if there is a bad KPI's result or not hit the target after a performance measurement program so that needed to address the problem [3].

\section{II.LITERATURE REVIEW}

In this chapter contains the theoretical basis that explains the various theories and concepts that are used as reference in this study. The theory discussed include theories about the concept of performance measurement, corporate performance measurement, KPKU concept, SWOT analysis and the concept of KPKU-BEF integration.

\section{A. Performance Measurement}

Definition of performance measurement is the quantification of the action, where the measurement is the process of quantification and action leads to performance. A further purpose of this performance is the efficiency and effectiveness of any action taken. More broadly performance measurement can be interpreted as a process of assessment of the progress achieved by the company in order to achieve the targets including an assessment of the efficiency of resources in providing products and services, the quality of the firm's output and effectiveness of the organization's activities in order to achieve organizational goals(5).

Performance measurement is very important for the organization as it provides much-needed guidance to management decision-making. Expand performance measurement functions opportunity to review the past and present and to obtain a future strategy for the organization's operations success and for the fulfilment of its strategic objective [5].

\section{B. Corporate Performance Measurement}

In the measurement of a company's performance, there are some terms commonly used, among others; performance measurement, performance measure and performance metrics. These terms are often used interchangeably 
2nd International Conference on Industrial and System Engineering (IConISE) and

7th Annual Conference on Industrial and System Engineering (ACISE) 2020

July $22^{\text {nd }}-23^{\text {rd }} 2020$, Surabaya, Indonesia

Table 1.

KPKU categories.

\begin{tabular}{cccc}
\hline \hline Number & Categories Content & Number & Categories Content \\
\hline 1 & Leadership with vision & 7 & Innovation management \\
2 & Excellence driven by costumers & 8 & Fact based management \\
3 & Organizational and Individual learn & 9 & Social responsibilities \\
4 & Award for employee and third parties & 10 & Result oriented and value creation \\
5 & Dexterity & 11 & System perspective \\
6 & Focus to the future & \\
\hline \hline
\end{tabular}

Table 2.

Levelling score.

\begin{tabular}{llll}
\hline \hline \multicolumn{1}{c}{ Level } & Band & Score range & Global image \\
\hline 8 & World Class Leader & $876-1000$ & Excellent \\
7 & Benchmark Leader & $776-875$ & Average \\
6 & Industry Leader & $676-775$ & \\
5 & Emerging Industry Leader & $576-675$ & \\
4 & Good Performance & $476-575$ & Poor \\
3 & Early Improvement & $376-475$ & \\
2 & Early Result & $276-375$ & $0-275$ \\
1 & Early Development & & \\
\hline \hline
\end{tabular}

Table 3.

SWOT Matrix Result

\begin{tabular}{|c|c|c|c|}
\hline \multicolumn{2}{|r|}{ PTRENGTH (S) } & \multicolumn{2}{|r|}{ WEAKNESS (W) } \\
\hline 1 & Resource competence on troubleshooting & 1 & $\begin{array}{l}\text { PLTGU's age exceed } 20 \text { years, not all asset rehabilitation conducted } \\
\text { and less reliability }\end{array}$ \\
\hline 2 & IMS already implemented & 2 & SIT utilization are not optimally conducted \\
\hline 3 & Internal rotation for resources with $60 \%$ millennials resource & 3 & Lean planning comprehension \\
\hline 4 & $\begin{array}{l}\text { Units could operate with two fuel type (Oil and/or gas fuel), } \\
\text { have free governor and black start facility }\end{array}$ & 4 & $\begin{array}{l}\text { Business process integration not optimal yet due to STO regulation } \\
\text { change }\end{array}$ \\
\hline 5 & $\begin{array}{l}\text { PLTGU unit has follower and peaker with CNG facility } \\
\text { capability }\end{array}$ & 5 & There is are unit (Karimunjawa) which have high BPP \\
\hline 6 & Business process already supported by IT & 6 & Gas Turbine main part assurance are not available yet \\
\hline 7 & Personnel have good IP AKSI culture & 7 & There are out of system unit (PLTU1, 2, Cilacap and Sunyaragi) \\
\hline 8 & Unit operational budget are in place & & \\
\hline \multicolumn{2}{|r|}{ OPPORTUNITY (O) } & \multicolumn{2}{|r|}{ THREAT (T) } \\
\hline 1 & $\begin{array}{l}\text { Electrical growth in Central Java 5.73\%, DIY } 4.32 \% \text { per year } \\
\text { (RUPTL 2019-2028) }\end{array}$ & 1 & Flood and land subsidence \\
\hline 2 & There is external certification institution & 2 & $\begin{array}{l}\text { Incoming PLTU Batang } 1900 \text { MW, PLTU TJB5, TJB6 } 2000 \text { MW on } \\
\text { 2020/2021 and IBT Kesugihan, Central Java }\end{array}$ \\
\hline 3 & Non-OEM product utilization potency & 3 & Gas supply decrease due to Kepodang gas field reduction \\
\hline 4 & $\begin{array}{l}\text { Technology development increase improvement opportunity for } \\
\text { reliability, efficiency, WPC and outage }\end{array}$ & 4 & Vessel activity on the Intake area due to free public area \\
\hline 5 & There is no peakers competitor in Central Java and DIY area yet & 5 & $\begin{array}{l}\text { The concept of setting SFC targets in the calculation of subsidies is in } \\
\text { place. }\end{array}$ \\
\hline 6 & Increase of supply gas potency & 6 & Economic uncertainty due to global sentiment affects supply prices. \\
\hline 7 & $\begin{array}{l}\text { HSD utility restriction from government so the cost production } \\
\text { more competitive }\end{array}$ & 7 & $\begin{array}{l}\text { The quality of work and competence of partners are not yet fully } \\
\text { optimal. }\end{array}$ \\
\hline 8 & $\begin{array}{l}\text { Improvement on third parties sourcing so the procurement could } \\
\text { be more competitive }\end{array}$ & 8 & Stricter emission-quality standards regulations. \\
\hline \multirow[t]{3}{*}{9} & $\begin{array}{l}\text { Digital and information technology development enhance the } \\
\text { personal knowledge and performance }\end{array}$ & 9 & Change in proper criteria (LCA). \\
\hline & & 10 & Retribution plan for seawater utilization. \\
\hline & & 11 & $\begin{array}{l}\text { Public demand for the PLTU location has increased. This demand is } \\
\text { related to issues and community empowerment. }\end{array}$ \\
\hline
\end{tabular}

however, to avoid confusion between the understanding of these terms, then it should be explained each difference. Performance measurement can be defined as the process efficiency and effectiveness of past actions quantification. Performance measures can be defined as a parameter that is used to quantify the efficiency and effectiveness of past actions. Performance metrics is the definition of the scope, content and the component parts of a broad-based measure of performance [6].

\section{Kriteria Performa Kinerja Unggul (KPKU)}

$\mathrm{KPKU}$ is an assessment system that purposed to guide, build, organize, and empowering the company's system and resources to achieve excellent performance assessment criteria adapted from Malcolm Baldrige Criteria for Performance Excellence(3). KPKU is consist of eleven important questionnaire categories that should be considered carefully to reach company's success related to process organizing and excellence result. KPKU Categories are described on Table 1. 
2nd International Conference on Industrial and System Engineering (IConISE) and

7th Annual Conference on Industrial and System Engineering (ACISE) 2020

July $22^{\text {nd }}-23^{\text {rd }} 2020$, Surabaya, Indonesia

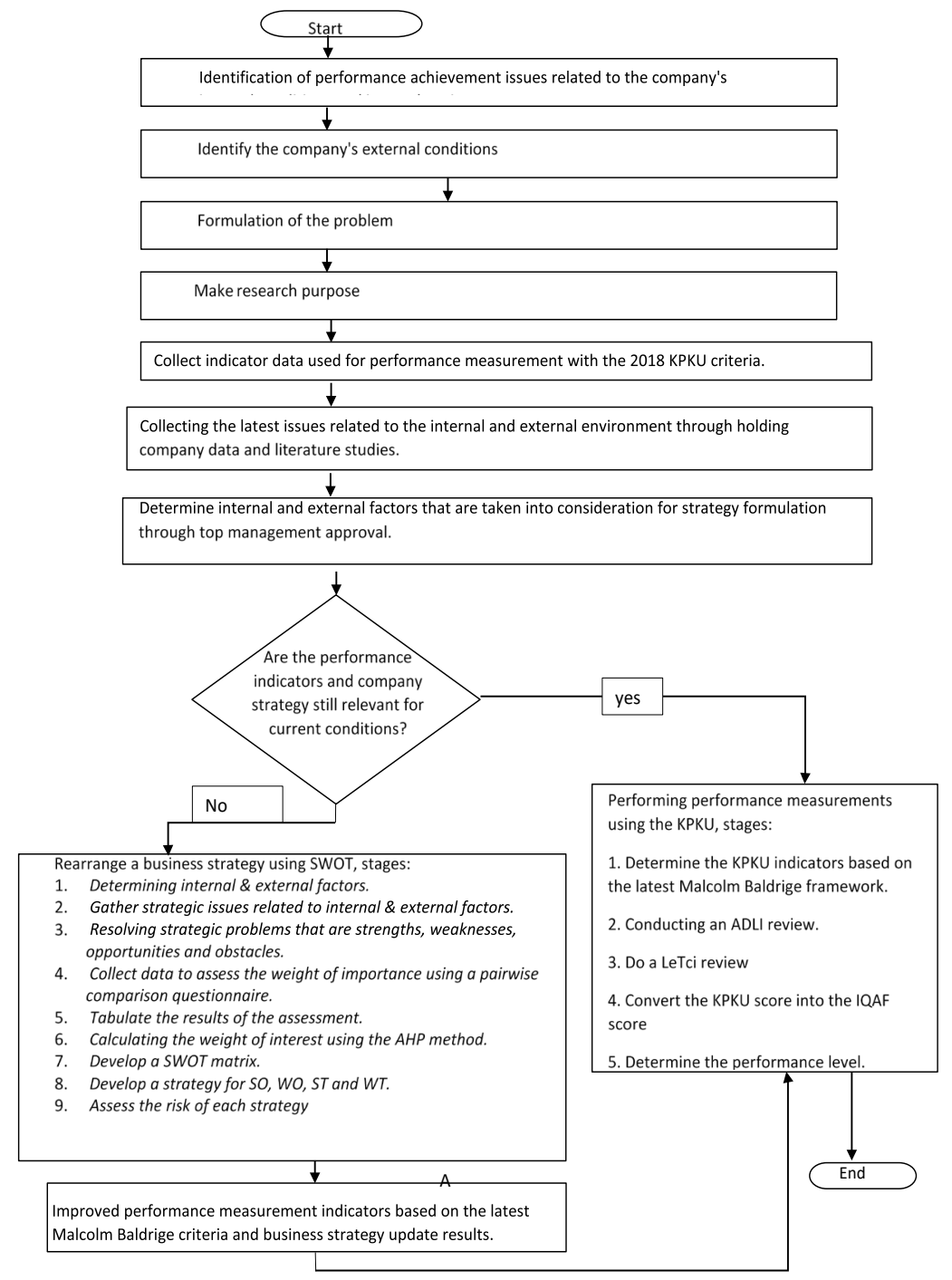

Figure 1. Methodology flow chart.

KPKU has been integrated with Baldrige Excellence Framework. Those integration items are as follows(3):

a. Synthesis - Comprehensive perspective of organization and developed by business attribute which included core competencies, strategic objectives, action plan and working system.

b. Alignment - Interconnection between KPKUs categories to ensure the plan, process, size and action consistence.

c. Integration - Built upon alignment so performance management system components fully interconnected operate and accomplish the target.

\section{SWOT Analysis}

SWOT analysis is a certain strategic planning method used to evaluate the strength, weakness, opportunities and threat in a project or business. SWOT analysis guides to identify positive and negative in the organization or company (SW) and outside it in an external environment (OT). From the analysis of the entire internal and external factors can produce four kinds of organizational strategy with their respective characteristics [7].

SWOT Matrix consist of four strategies type of improvement, as follows:

a. SO Strategy - optimize the existing internal strength to utilize existing external strength

b. WO Strategy - fix the internal weakness with maximize the opportunity from external influence

c. ST Strategy - utilize the existing strength to minimize external threat effect

d. WT Strategy - defensive tactical for minimize internal weakness effect and avoid external threat

KPKU describes that the initial step actualization of Malcolm Baldrige concept is to clarify the vision and strategy that utilized by the company. As the organizational key-strategic that should be measured, Malcolm Baldrige concept provides the implementation of effective system but not to choose right strategy. With implement the SWOT 
2nd International Conference on Industrial and System Engineering (IConISE) and

7 th Annual Conference on Industrial and System Engineering (ACISE) 2020

July $22^{\text {nd }}-23^{\text {rd }} 2020$, Surabaya, Indonesia

Tabel 4.

Weight from each issue.

\begin{tabular}{|c|c|c|c|c|c|c|c|c|c|}
\hline No & Code & Weight & Rating & $\begin{array}{c}\text { Weight } x \\
\text { Rating }\end{array}$ & No & Code & Weight & Rating & $\begin{array}{c}\text { Weight } x \\
\text { Rating }\end{array}$ \\
\hline 1 & S1 & 0.229 & 2 & 0.459 & 1 & $\mathrm{~T} 4$ & 0.107 & 4 & 0.430 \\
\hline 2 & S2 & 0.165 & 2 & 0.331 & 2 & T5 & 0.103 & 2 & 0.207 \\
\hline 3 & S3 & 0.156 & 3 & 0.468 & 3 & T6 & 0.088 & 3 & 0.263 \\
\hline 4 & S4 & 0.120 & 4 & 0.481 & 4 & $\mathrm{~T} 7$ & 0.071 & 5 & 0.354 \\
\hline 5 & S5 & 0.113 & 2 & 0.225 & 5 & $\mathrm{~T} 8$ & 0.057 & 5 & 0.283 \\
\hline 6 & S6 & 0.076 & 5 & 0.380 & 6 & T9 & 0.057 & 5 & 0.285 \\
\hline 7 & S7 & 0.083 & 2 & 0.166 & 7 & $\mathrm{~T} 10$ & 0.067 & 2 & 0.134 \\
\hline 8 & S8 & 0.057 & 2 & 0.114 & 8 & $\mathrm{~T} 11$ & 0.045 & 5 & 0.224 \\
\hline 9 & W1 & 0.230 & 4 & 0.918 & 9 & O1 & 0.050 & 3 & 0.149 \\
\hline 10 & W2 & 0.175 & 4 & 0.700 & 10 & $\mathrm{O} 2$ & 0.062 & 3 & 0.186 \\
\hline 11 & W3 & 0.150 & 3 & 0.451 & 11 & $\mathrm{O} 3$ & 0.090 & 3 & 0.271 \\
\hline 12 & W4 & 0.144 & 3 & 0.431 & 12 & $\mathrm{O} 4$ & 0.089 & 2 & 0.177 \\
\hline 13 & W5 & 0.120 & 2 & 0.240 & 13 & O5 & 0.108 & 4 & 0.433 \\
\hline 14 & W6 & 0.084 & 5 & 0.420 & 14 & O6 & 0.115 & 3 & 0.346 \\
\hline 15 & W7 & 0.098 & 2 & 0.196 & 15 & O7 & 0.132 & 4 & 0.529 \\
\hline 16 & $\mathrm{~T} 1$ & 0.153 & 2 & 0.307 & 16 & O8 & 0.162 & 3 & 0.486 \\
\hline 17 & $\mathrm{~T} 2$ & 0.139 & 2 & 0.279 & 17 & O9 & 0.192 & 4 & 0.767 \\
\hline 18 & $\mathrm{~T} 3$ & 0.113 & 4 & 0.450 & 18 & & & & \\
\hline
\end{tabular}

Table 5 .

Strength and weakness Identification from SWOT analysis matrix

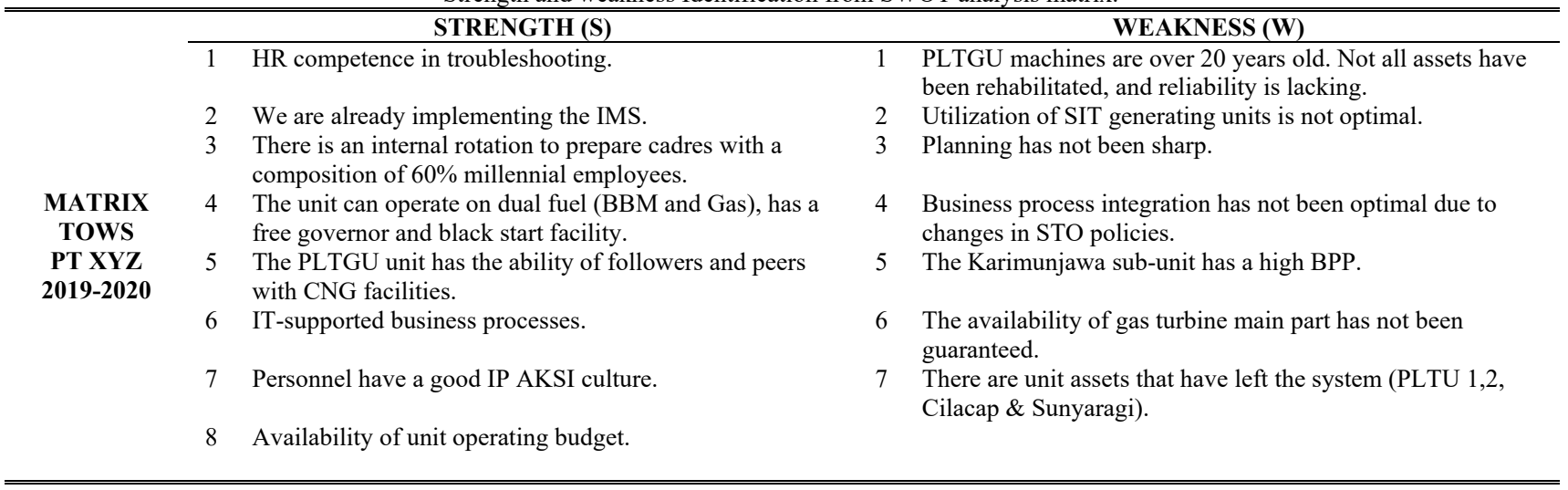

analysis procedure so the produced strategies could be used as improvement of Malcolm Baldrige concept baseline [3].

\section{METHODOLOGY}

General methodology implemented in this research is case study and problem solving in the specific phase of comprehensive business process of an industrial and service company and the research methodology in this study can be seen in Figure 1. Data collecting method that used are as follows:

a. Documentation study - data generating method that conducted by related-problem document research

b. Direct observation - observe company operational activity directly to get the big picture related to situation and condition related to research items. Internal business process mapping also provided in this research to describe information flow between company division

c. Interview - Interview several division heads of the company related to internal business process information analysis.

Figure 1 show the methods from this research. Detail step from this methodology can show bellow:

1. Identify Internal and External Issue.
2. Identify strength and weakness from internal PT.XYZ.

3. Identify opportunity and threat from external environment PT.XYZ

4. Calculate weight from each issue using AHP technique. Detail step in AHP

a. Collect data using pairwise comparison questionnaire.

b. Transform data to pairwise comparation matrix.

c. Calculate weight/eigen value.

d. Consistency test:

i. Calculate $\mathrm{CI}$ (consistency index)

ii. Choose IR value based on matrix size. Matrix size determines as the total of criteria.

iii. Calculate $\mathrm{CR}$ value. Compare $\mathrm{CR}$ value, if $\mathrm{CR}$ value less than 0.1 , the result is consistent.

5. Make So, ST, WO and WT strategy based on top 3 weight.

Detail step to evaluate $\mathrm{XYZ}$ performance using KPKU methods show bellow:

1. Review ADLI

2. Scoring based on ADLI.

3. Review LeTCI

4. Scoring based on LeTCI rule.

5. Convert score KPKU to IQAF

6. Calculate Overall score KPKU 
2nd International Conference on Industrial and System Engineering (IConISE) and

7th Annual Conference on Industrial and System Engineering (ACISE) 2020

July $22^{\text {nd }}-23^{\text {rd }} 2020$, Surabaya, Indonesia

Table 6.

The strategies.

\begin{tabular}{|c|c|c|c|c|c|}
\hline & OPPORTUNITY (O) & \multicolumn{2}{|r|}{ STRATEGY "SO" } & \multicolumn{2}{|r|}{ "STRATEGY "WO" } \\
\hline 1 & $\begin{array}{l}\text { The growth of electricity in the Central Java area is } \\
5.73 \% \text { DIY } 4.32 \% \text { / year (RUPTL 2019-2028). }\end{array}$ & 1 & $\begin{array}{l}\text { Increase competence, } \\
\text { certification and program } \\
\text { expertise }(\mathrm{S} 1, \mathrm{~S} 3, \mathrm{O} 2, \mathrm{O} 9)\end{array}$ & 1 & $\begin{array}{l}\text { We are optimizing the use of energy } \\
\text { efficiency and PS reduction program } \\
\text { operating strategies (W1, O1, O7). }\end{array}$ \\
\hline 2 & $\begin{array}{l}\text { There is a certification/competency body from } \\
\text { external. }\end{array}$ & 2 & $\begin{array}{l}\text { Improve the reliability and } \\
\text { efficiency of generating } \\
\text { equipment (S2, O1, O4, O8, } \\
\text { O9). }\end{array}$ & 2 & $\begin{array}{l}\text { Idle Asset Management (PLTU 1,2, PLTG } \\
\text { Cilacap, Sunyaragi) and PLTD Karimun } \\
\text { Jawa following Company Policy (W5, W7, } \\
\text { O7). }\end{array}$ \\
\hline 3 & Potential of using non-OEM products. & 3 & $\begin{array}{l}\text { Improve generator } \\
\text { governance (S4, S5, S6, S7 } \\
\mathrm{S} 8, \mathrm{O} 1, \mathrm{O} 2, \mathrm{O} 3, \mathrm{O} 5, \mathrm{O} 6, \mathrm{O} 9) .\end{array}$ & 3 & $\begin{array}{l}\text { Increase competence, certification and } \\
\text { program expertise (W3, O2, O9). }\end{array}$ \\
\hline 4 & $\begin{array}{l}\text { Increasingly developing technology increases the } \\
\text { opportunities for improvement for reliability, } \\
\text { efficiency, WPC and Outage. }\end{array}$ & & & 4 & $\begin{array}{l}\text { Implementation of digital transformation } \\
\text { (W2, W6, O9). }\end{array}$ \\
\hline 5 & $\begin{array}{l}\text { There are no competing peakers in the DIY Central } \\
\text { Java region. }\end{array}$ & & & 5 & $\begin{array}{l}\text { Improve generator governance }(\mathrm{W} 4, \mathrm{O} 1 \text {, } \\
\mathrm{O} 2, \mathrm{O} 3, \mathrm{O} 5, \mathrm{O} 6, \mathrm{O} 9) \text {. }\end{array}$ \\
\hline 6 & Potential for increased gas supply. & & & 6 & $\begin{array}{l}\text { Improve the reliability and efficiency of } \\
\text { generating equipment (W1, O1, O4, O8, } \\
\text { O9) }\end{array}$ \\
\hline 7 & $\begin{array}{l}\text { Restrictions on the use of HSD by the Government } \\
\text { have resulted in more competitive prices for } \\
\text { production costs. }\end{array}$ & & & & \\
\hline 8 & $\begin{array}{l}\text { Increase in sourcing partners so that procurement } \\
\text { prices can be more competitive. }\end{array}$ & & & & \\
\hline 9 & $\begin{array}{l}\text { The development of digital and information } \\
\text { technology increases the adequacy of information to } \\
\text { increase personal insight and to improve performance. }\end{array}$ & & & & \\
\hline
\end{tabular}

Table 7.

The threats strategy.

\begin{tabular}{|c|c|c|c|c|c|}
\hline \multicolumn{2}{|r|}{ THREAT (T) } & \multicolumn{2}{|r|}{ STRATEGY "ST" } & \multicolumn{2}{|r|}{ STRATEGY "WT" } \\
\hline 1 & Flood/Rob and Land Subsidence & 1 & $\begin{array}{l}\text { Improve QA and QC work } \\
\text { carried out by External and } \\
\text { Internal (S6, T7). }\end{array}$ & 1 & $\begin{array}{l}\text { OM LCM and CBM based generators for } \\
\text { PLTGU block 1-2 (W2, T5). }\end{array}$ \\
\hline 2 & $\begin{array}{l}\text { Incoming PLTU Batang } 1900 \mathrm{MW}, \text { PLTU } \\
\text { TJB5, TJB6 } 2000 \mathrm{MW} \text { on 2020/2021 and IBT } \\
\text { Kesugihan, Central Java }\end{array}$ & 2 & $\begin{array}{l}\text { Increasing Competence, } \\
\text { certification, and expertise } \\
\text { programs }(\mathrm{S} 1, \mathrm{~S} 3, \mathrm{~T} 8) .\end{array}$ & 2 & $\begin{array}{l}\text { Optimization of the Operational Strategy of } \\
\text { the Energy Efficiency program and PS } \\
\text { reduction }(\mathrm{W} 1, \mathrm{~T} 2, \mathrm{~T} 5, \mathrm{~T} 8) \text {. }\end{array}$ \\
\hline 3 & $\begin{array}{l}\text { Gas supply decrease due to Kepodang gas field } \\
\text { reduction }\end{array}$ & 3 & $\begin{array}{l}\text { Improvement reliability and } \\
\text { efficiency of generating } \\
\text { equipment }(\mathrm{S} 2, \mathrm{~T} 2) \text {. }\end{array}$ & 3 & $\begin{array}{l}\text { Improvement of the reliability and efficiency } \\
\text { of generating equipment (W1, T2, T5). }\end{array}$ \\
\hline 4 & $\begin{array}{l}\text { Vessel activity on the Intake area due to free } \\
\text { public area }\end{array}$ & 4 & $\begin{array}{l}\text { Improving generator governance } \\
(\mathrm{S} 5, \mathrm{~S} 6, \mathrm{~T} 4, \mathrm{~T} 5, \mathrm{~T} 6) .\end{array}$ & 4 & $\begin{array}{l}\text { Implementation of digital transformation (W2, } \\
\text { W6, T6). }\end{array}$ \\
\hline 5 & $\begin{array}{l}\text { The concept of setting SFC targets in the } \\
\text { calculation of subsidies is in place. }\end{array}$ & 5 & $\begin{array}{l}\text { Improve management } \\
\text { stakeholders (S2, S7, T10,T11). }\end{array}$ & 5 & $\begin{array}{l}\text { Increase monitoring and reduce plant } \\
\text { emissions }(\mathrm{T} 8, \mathrm{~T} 9, \mathrm{~W} 1) \text {. }\end{array}$ \\
\hline 6 & $\begin{array}{l}\text { Economic uncertainty due to global sentiment } \\
\text { affects supply prices. }\end{array}$ & 6 & $\begin{array}{l}\text { Improve the management of } \\
\text { Primary Energy }(\mathrm{T} 3, \mathrm{~S} 4) \text {. }\end{array}$ & 6 & $\begin{array}{l}\text { Increase management stakeholders (W1, T4, } \\
\text { T11 }\end{array}$ \\
\hline 7 & $\begin{array}{l}\text { The quality of work and competence of } \\
\text { partners are not yet fully optimal. }\end{array}$ & & & 7 & $\begin{array}{l}\text { Improving power plan management (W1, W2, } \\
\mathrm{W} 3, \mathrm{~W} 4, \mathrm{~W} 6, \mathrm{~T} 2, \mathrm{~T} 3, \mathrm{~T} 4, \mathrm{~T} 5, \mathrm{~T} 6)) \text {. }\end{array}$ \\
\hline 8 & Stricter emission-quality standards regulations. & & & & \\
\hline 9 & Change in proper criteria (LCA). & & & & \\
\hline 10 & Retribution plan for seawater utilization. & & & & \\
\hline 11 & $\begin{array}{l}\text { Public demand for the PLTU location has } \\
\text { increased. This demand is related to issues and } \\
\text { community empowerment. }\end{array}$ & & & & \\
\hline
\end{tabular}

7. Levelling overall score, levelling classification show in Table 2.

\section{RESULT}

Research respondents were The Balmon users in SWOT analysis is a part of planning process. The main concern is in every planning process, an enterprise needs an assessment related current and future condition which affect target achieving process of the institution. The right strategic implementation for the company started with define the opportunities and threats that existed in the circumstance and then understanding the strengths and weaknesses from inside of the company. So the company could compete and complete the target effectively and efficiently. The result of the SWOT analysis is described on Table 3 . The weight from each strategic issue show in Table 4. The weight calculates using AHP method.

The combination of KPKU and SWOT method implementation produces the specific improvement. That 
2nd International Conference on Industrial and System Engineering (IConISE) and

7th Annual Conference on Industrial and System Engineering (ACISE) 2020

July $22^{\text {nd }}-23^{\text {rd }} 2020$, Surabaya, Indonesia

Table 8.

KPKU result.

\begin{tabular}{|c|c|c|c|c|c|}
\hline No & Category & Items & Point value & IQQAF(\%) & Overall Score \\
\hline \multirow{2}{*}{1} & \multirow{2}{*}{ Leadership (C1) } & Senior leadership (11) & 70 & 65 & 45.5 \\
\hline & & Governance and social responsibilities (12) & 50 & 65 & 32.5 \\
\hline \multirow{2}{*}{2} & \multirow{2}{*}{ Strategic planning $(\mathrm{C} 2)$} & Strategy development (13) & 40 & 65 & 26 \\
\hline & & Strategy implementation (14) & 45 & 65 & 29.25 \\
\hline \multirow{2}{*}{3} & \multirow{2}{*}{ Customer focus (C3) } & Customer engagement (15) & 45 & 60 & 27 \\
\hline & & Customer expectation(16) & 40 & 60 & 24 \\
\hline \multirow[t]{2}{*}{4} & \multirow{2}{*}{$\begin{array}{l}\text { Measurement, analysis, and } \\
\text { knowledge management (C4) }\end{array}$} & $\begin{array}{c}\text { Measurement, analysis, and improvement of } \\
\text { organizational performance }\end{array}$ & 45 & 55 & 24.75 \\
\hline & & Information and management of knowledge & 45 & 60 & 27 \\
\hline \multirow{2}{*}{5} & \multirow{2}{*}{ Workforce focus (C5) } & Workforce engagement (I9) & 45 & 65 & 26 \\
\hline & & Workforce environment (I10) & 40 & 65 & 29.25 \\
\hline \multirow{4}{*}{6} & \multirow{2}{*}{ Process management (C6) } & Work systems (I11) & 45 & 65 & 29.25 \\
\hline & & Operational Effectiveness (I12) & 40 & 65 & 26 \\
\hline & & Product and process outcomes (113) & 120 & 60 & 72 \\
\hline & & Customer focused outcomes & 80 & 60 & 48 \\
\hline \multirow[t]{4}{*}{7} & Results (C7) & Financial, market and strategy outcomes & 80 & 55 & 44 \\
\hline & & Workforce focused outcomes & 80 & 60 & 48 \\
\hline & & Leadership and governance outcomes & 90 & 60 & 54 \\
\hline & & Total & & \multicolumn{2}{|r|}{612.5} \\
\hline
\end{tabular}

Table 9.

KPI target planning table.

\begin{tabular}{|c|c|c|c|c|c|c|c|c|}
\hline \multirow{2}{*}{ No } & Strategic & \multirow{2}{*}{ KPI } & \multirow{2}{*}{ Unit } & \multicolumn{5}{|c|}{ Target } \\
\hline & Objectives & & & 2019 & 2020 & 2021 & 2022 & 2023 \\
\hline SO5 & $\begin{array}{l}\text { Increased Customer } \\
\text { Satisfaction }\end{array}$ & $\begin{array}{c}\text { Customer } \\
\text { Satisfaction Level }\end{array}$ & Index & $82.43 \%$ & $82.48 \%$ & $82.53 \%$ & $82.58 \%$ & $82.63 \%$ \\
\hline $\mathrm{SO} 2$ & Optimizing Cost. & BPP & $\mathrm{Rp} / \mathrm{kWh}$ & $1,258.73$ & $1,315.78$ & $1,373.73$ & $1,432.54$ & $1,484.06$ \\
\hline \multirow{3}{*}{ SO6 } & \multirow{3}{*}{$\begin{array}{l}\text { Increase in Power } \\
\text { Plant Operation } \\
\text { Performance }\end{array}$} & $\begin{array}{l}\text { Availability } \\
\text { (EAF) }\end{array}$ & $\%$ & 91.53 & 91.58 & 95.48 & 92.13 & 92.17 \\
\hline & & $\begin{array}{l}\text { Reliability } \\
\text { (EFOR) }\end{array}$ & $\%$ & 5.87 & 3.98 & 3.87 & 2.94 & 2.56 \\
\hline & & NPHR & $\mathrm{kCal} / \mathrm{kWh}$ & $2,598.31$ & $2,254.04$ & $2,261.97$ & $2,270.14$ & $2,250.69$ \\
\hline $\mathrm{SO} 7$ & $\begin{array}{l}\text { Asset Management } \\
\text { Improvement }\end{array}$ & $\begin{array}{c}\text { Asset } \\
\text { Management } \\
\text { Maturity Level }\end{array}$ & Score & 3.86 & 3.91 & 4.00 & 4.06 & 4.14 \\
\hline \multirow{3}{*}{ SO12 } & \multirow{3}{*}{$\begin{array}{l}\text { Community \& HSE } \\
\text { Excellence. }\end{array}$} & $\begin{array}{l}\text { Environment: } \\
\text { PROPER }\end{array}$ & $\begin{array}{l}\text { PROPER } \\
\text { HIJAU }\end{array}$ & Hijau & Hijau & Hijau & Hijau & Hijau \\
\hline & & $\begin{array}{l}\text { K3: Zero } \\
\text { Accident }\end{array}$ & Rate & 0 & 0 & 0 & 0 & 0 \\
\hline & & $\begin{array}{l}\text { Unit Cleanliness } \\
\text { Index }\end{array}$ & Index & $2 \mathrm{~B}$ & $2 \mathrm{~B}$ & $2 \mathrm{~B}$ & $2 \mathrm{~B}$ & $2 \mathrm{~A}$ \\
\hline \multirow[b]{2}{*}{ SO15 } & $\begin{array}{l}\text { Increase the } \\
\text { capacity and }\end{array}$ & $\begin{array}{c}\text { Human Capital } \\
\text { Readiness (HCR) }\end{array}$ & Level Maturities & 4.45 & 4.50 & 4.50 & 4.55 & 4.55 \\
\hline & $\begin{array}{l}\text { capability of HC } \\
\text { and Leadership Fit } \\
\text { to industry } 4.0\end{array}$ & $\begin{array}{c}\text { Organizational } \\
\text { Capital Readiness } \\
\text { (OCR) }\end{array}$ & Level Maturities & 4.45 & 4.50 & 4.50 & 4.55 & 4.55 \\
\hline SO16 & $\begin{array}{c}\text { Information Capital } \\
\text { Readiness }\end{array}$ & $\begin{array}{l}\text { ICR (Information } \\
\text { Capital } \\
\text { Readiness) }\end{array}$ & Level Maturities & 4.15 & 4.18 & 4.21 & 4.23 & 4.25 \\
\hline
\end{tabular}

improvement generally affects multi-division approach on PT XYZ, or called SWOT alternative strategy are described on Table $5-7$.

The Table 6 is describing the strategy and the Table 7 describing the treats. Based on the SWOT analysis matrix result above and the business process approach, there are eight main strategy PT XYZ defined on the Power Generation Plan 2019 - 2020. The resume list of Power Generation Plan 2019 -2020 are as follows:

1. Improve the competencies, certification, and program expertise

2. Improvement on reliability and power generation equipment efficiency

3. Improve power generation management

4. Digital transformation implementation
5. Quality assurance and quality control improvement

6. Improve monitoring and reduce the emission

7. Improve stakeholder management

8. Primary energy utility improvement

The result from KPKU evaluation show on the Table 8 .

As per PT XYZ vision and mission and differentiate of strategic objectives of corporate, seven Strategic Objectives (SO) are produced which correlate with Strategic Map. From the Strategic Map there are two SO in Leading Indicator (SO1 for Customer segment and SO2 for Financial segment). In other hand there are five SO represented Lagging Indicator, those are: $\mathrm{SO} 3, \mathrm{SO} 4, \mathrm{SO} 5$ for Internal Business Process segment; SO6 and SO7 for Learning and Growth segment. Correlation those seven SO's on the 
2nd International Conference on Industrial and System Engineering (IConISE) and

7 th Annual Conference on Industrial and System Engineering (ACISE) 2020

July $22^{\text {nd }}-23^{\text {rd }} 2020$, Surabaya, Indonesia

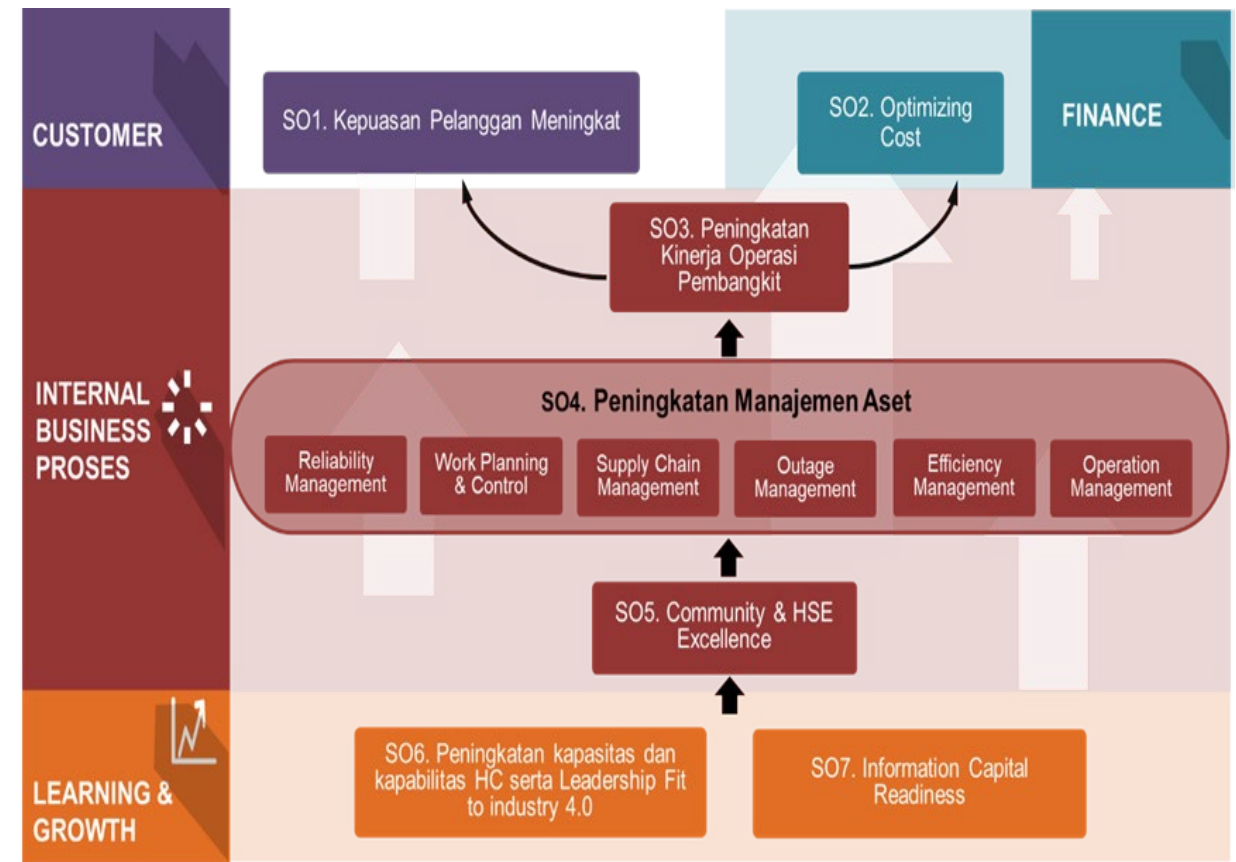

Figure 2. Strategic Map.

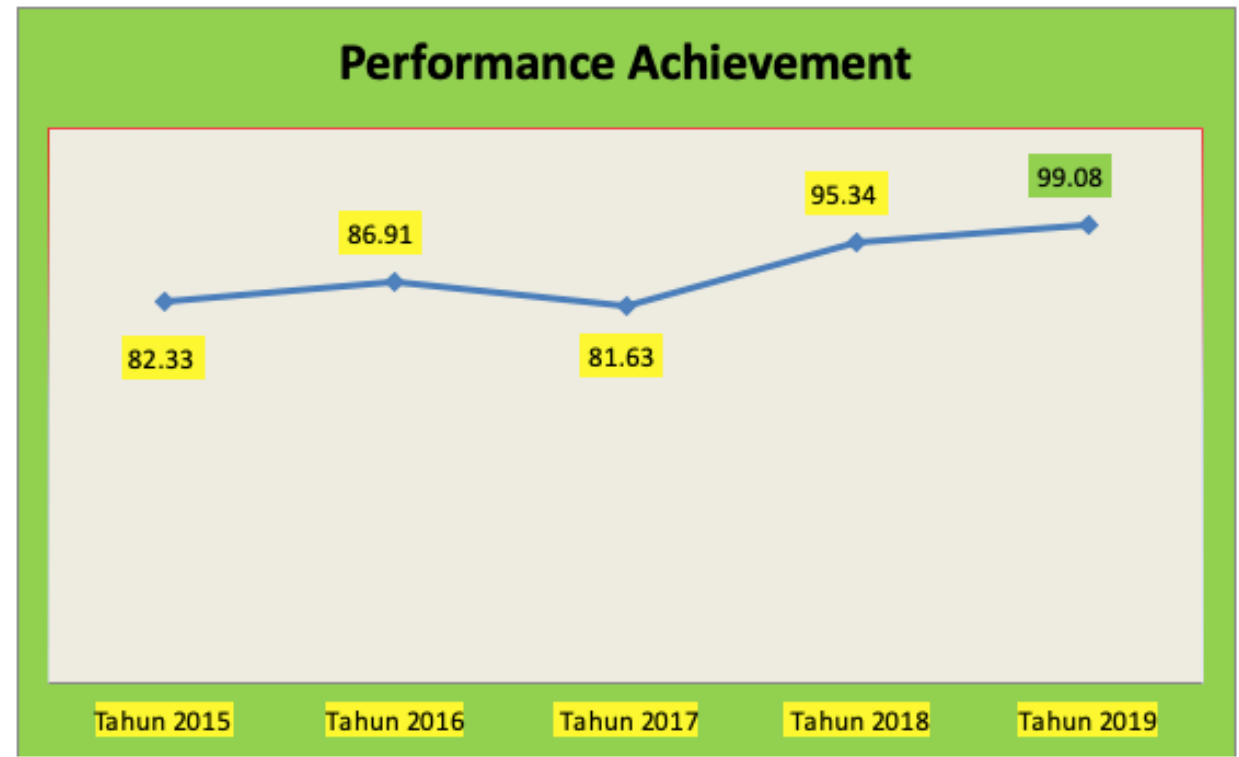

Figure 3. Performance achievement.

Strategic Map as seen on figure 2 have defined for evaluate the completion of Main Unit Strategy at PT XYZ.

The most importance strategy for PT.XYZ is "Improve the competence, certification and program expertise. The calculation score from the KPKU evaluation criteria is 612.5. The evaluation results show that PT. XYZ has average capabilities and has an industry leader band. The combination of KPKU and SWOT method implementation produces a specific strategy. The strategy is used as a role to make improvement plans to achieve World class band leaders. Each of SO defined on Strategic Map derived into KPI SO which existed on the Table 8.
Risk Study Power Generation Plant could be produced as a derivative of KPI Target Planning Table 9. The Risk Study result as follows:

1. Customer satisfaction are increased, measured by the five years target average (Index 82.53)

2. Cost optimizing, measured by five years Main Production Cost target average (1372.96 Rp/kWh)

3. Power plant operation performance improvement, measured by the five years Equivalent Availability Factor target average (Index 92.57\%), Equivalent Force Outage Rate (Index 3.84\%), Net Plant Heat Rate (Index $2327.03 \mathrm{kcal} / \mathrm{kWh})$ 
2nd International Conference on Industrial and System Engineering (IConISE) and

7 th Annual Conference on Industrial and System Engineering (ACISE) 2020

July $22^{\text {nd }}-23^{\text {rd }} 2020$, Surabaya, Indonesia

4. Asset Management Improvement, measured by the maturity level of asset management five years target average (Level 3.98)

5. Community and HSE Excellence, measured by five years target of environment management: Green PROPER, K3: Frequency Rate 0 and Index Unit Cleanliness: 3A become $2 \mathrm{~B}$

6. HC capacity and capability improvement and leadership fit to industry 4.0 , measured by average target maturity five years HCR: Level 4.51, OCR: Level 4.51 and Employee Engagement Index: 96.7

7. Information Capital Readiness measured by average target maturity five years: Level 4.2

Risk study developed for identify risk potential commenced due to KPI SO completion. Based on Risk Study then will be implemented mitigation plan that represented Strategic Initiative (SI) and Sub SI. Based on Risk Study result above related to KPI SO completion, Strategic Initiative described in table appendix $\mathrm{A}$ in Appendices.

The result from the improvement show in Figure 3. Figure 3 above shows the performance achievements from 2015 to 2019 . The following are the conclusions in this study

1. Continuously improve the work process considering follow up from meeting or review and analyze based on the fact (related data outcome process)

2. KPI analysis drafting and PI which supporting KPI, completed with the competitor data/information, segmentation and projection

3. Fixing the overdue performance with make some specific strategic program and conduct monitoring progress weekly until produced a trend to accomplish.

4. Maintain and improve performance achievement for improvement, improved trend (sustain and/or favorable) and leading over the competitors.

\section{V.CONCLUSION}

The conclusion from our research :

The result from SWOT analysis consist of 8 strategy, The strategies are as follows:

1. Improve the competencies, certification, and program expertise

2. Improvement of reliability and power generation equipment efficiency

3. Improve power generation management

4. Digital transformation implementation

5. Quality assurance and quality control improvement

6. Improve monitoring and reduce the emission

7. Improve stakeholder management

8. Primary energy utility improvement

The calculation score from the KPKU evaluation criteria is 612.5. The result means that PT.XYZ has an industry leader band.
[2]. Rusev SJ, Salonitis K 2016 Operational Excellence Assessment Framework for Manufacturing Companies. Procedia CIRP. 255:2727. doi.org/10.1016/j.procir.2016.08.026

[3]. Eka Rahayu Estuningsari, Nasir Widha Setyanto RYE 2013 PENGUKURAN KINERJA PERUSAHAAN BERBASIS KRITERIA PENILAIAN KINERJA UNGGUL ( KPKU ) BUMN ( Studi Kasus: Perum Jasa Tirta 1 Malang ) PERFORMANCE MEASUREMENT BASED COMPANY SUPERIOR PERFORMANCE CRITERIA ( KPKU ) BUMN ( Case study: Perum Jasa Tirta 1 Malang, ,. Univ Brawijaya. 2013;476-87.

[4]. Yongvanich K, Guthrie J 2006 An extended performance reporting framework for social and environmental accounting. Bus Strateg Environ. 15(5):309-21.

[5]. Gawankar SA, Kamble S, Raut R 2017 An investigation of the relationship between supply chain management practices (SCMP) on supply chain performance measurement (SCPM) of Indian retail chain using SEM. Benchmarking. Emerald 24(1):257-95. doi.org/10.1108/bij-12-2015-0123

[6]. Neely A, Gregory M, Platts K 2005 Performance measurement system design: A literature review and research agenda. Int J Oper Prod Manag. 25(12):1228-63.

[7]. Tools JM 2017 SWOT ANALYSIS: A THEORETICAL REVIEW. 7(1):45-56. Available from: https://www.researchgate.net/publication/319367788_SWOT_ANA LYSIS_A_THEORETICAL_REVIEW.

\section{REFERENCES}

[1]. Otley D 1999 Performance management: A framework for management control systems research. Manag Account Res. 10(4) p $363-82$. 
2nd International Conference on Industrial and System Engineering (IConISE) and

7th Annual Conference on Industrial and System Engineering (ACISE) 2020

July $22^{\text {nd }}-23^{\text {rd }} 2020$, Surabaya, Indonesia

APPENDICES

Appendix A. Strategic initiative table.

\begin{tabular}{|c|c|c|c|c|}
\hline No & & & Strategic Initiatives \& Sub - Strategic Initiatives & PIC \\
\hline & \multirow{6}{*}{ SI 01} & Prog & $\begin{array}{l}\text { I to Increase Availability and Reliability of Power Plants managed by the } \\
\text { Company. }\end{array}$ & EVP RIE \\
\hline 1 & & 1.1 & $\begin{array}{l}\text { Rehabilitation, Repowering, Retrofit and Life Extension Program for } \\
\text { Generating Units. }\end{array}$ & MENG, MHAR \\
\hline 2 & & 1.3 & Smart Inventory Management Program & MHAR \\
\hline 3 & & 1.6 & $\begin{array}{l}\text { Collaboration with academics. Practitioners and manufacturers to increase } \\
\text { reliability and efficiency. }\end{array}$ & MENG, MOPR \\
\hline 4 & & 1.7 & Strengthening Capacity and Capability of Periodic Maintenance. & MHAR \\
\hline \multirow[t]{2}{*}{5} & & 1.8 & Best Practice Preservation Program (mothballed powerplant) & MOPR \\
\hline & \multirow{5}{*}{ SI 03} & Smart & $\begin{array}{c}\text { erprise Asset Management (Stabilize. Improve. Optimise. Sustain and Well } \\
\text { Being) }\end{array}$ & VP PWG I, II.1 \& II.2 \\
\hline 6 & & 3.1 & Digitizing Work Planning \& Control. & MHAR \\
\hline 7 & & 3.2 & Enhancing Asset Management Culture based on CERIA CULTURE. & MADM \\
\hline 8 & & 3.5 & Improvement of Asset Management Governance. & ATKP \\
\hline \multirow[t]{2}{*}{9} & & 3.6 & Increased effectiveness of Life Cycle Management (LCM). & MENG \\
\hline & \multirow[b]{2}{*}{ SI 04} & & Implementasi Manajemen Energi Primer Excellent & VP PRE I \\
\hline \multirow[t]{2}{*}{10} & & 4.3 & $\begin{array}{l}\text { Management of Primary Energy Excellent to improve Generator Efficiency } \\
\text { and Competitiveness. }\end{array}$ & MOPR \\
\hline & \multirow{8}{*}{ SI 10} & & Implementasi Roadmap Community \& HSE Excellence & VP HSE \\
\hline 11 & & 10.1 & Program for Compliance Compliance and Improvement of Emission Control. & MOPR \\
\hline 12 & & 10.2 & Environmental PROPER Fulfillment Program. & MOPR \\
\hline 13 & & 10.3 & Hazardous and Non-B3 Waste Management. & MOPR \\
\hline 14 & & 10.4 & $\begin{array}{l}\text { Liquid Waste Compliance Fulfillment Program and Reduction of Liquid Waste } \\
\text { Load. }\end{array}$ & MOPR \\
\hline 15 & & 10.5 & CSMS (Contractor Safety Management System) implementation. & MOPR \\
\hline 16 & & 10.6 & Digitalization of HSS (Health Safety and Security) Business Processes. & MOPR \\
\hline 17 & & 10.7 & Energy Audit Program and Emission Reduction Efforts. & MOPR,MENG \\
\hline \multirow{3}{*}{18} & \multirow[t]{2}{*}{ SI 11} & \multicolumn{2}{|c|}{$\begin{array}{l}\text { Development of Knowledge Management (KM) Processes that Encourage Strategic } \\
\text { Innovation. }\end{array}$} & EVP RIE \\
\hline & & 11.3 & Innovation Dissemination Program. & MENG \\
\hline & \multirow{2}{*}{ SI 12} & & Strengthening the Engineering Support Function. & EVP RIE \\
\hline \multirow[t]{2}{*}{19} & & 12.4 & TOR Quality Improvement in Supporting the Procurement Process. & MENG \\
\hline & \multirow{2}{*}{ SI 14} & Roadn & development and implementation of the digital transformation platform. & EVP RIE \\
\hline \multirow[t]{2}{*}{20} & & 14.3 & Digital Work Culture Transformation & MADM, MENG \\
\hline & \multirow{6}{*}{ SI 16} & Implem & ation of Learning Value Chain-based Employee Competency Development. & VP HCD \\
\hline 21 & & 16.1 & $\begin{array}{l}\text { Implementation of LNA (Learning Need Analysis) Compilation Based on } \\
\text { Corporate University. }\end{array}$ & MADM \\
\hline 22 & & 16.9 & OME Competency Acceleration in IP Group. & MADM \\
\hline 23 & & 16.12 & Asset Management Capacity Building & MADM, ATKP \\
\hline 24 & & 16.14 & $\begin{array}{l}\text { Increased Expertise Capability for Problem Solving in Problems. } \\
\text { Repeat Generation (Chronic) and Business Development. }\end{array}$ & MADM \\
\hline \multirow[t]{2}{*}{25} & & 16.15 & Health Safety and Security Advance Training. & MADM, MOPR \\
\hline & \multirow{6}{*}{ SI 01} & & $\begin{array}{l}\text { m to Increase Availability and Reliability of Power Plants managed by the } \\
\text { Company }\end{array}$ & EVP RIE \\
\hline 1 & & 1.1 & $\begin{array}{l}\text { Rehabilitation, Repowering, Retrofit and Life Extension Program for Generating } \\
\text { Units. }\end{array}$ & MENG, MHAR \\
\hline 2 & & 1.3 & Smart Inventory Management Program. & MHAR \\
\hline 3 & & 1.6 & $\begin{array}{l}\text { Collaboration with academics. Practitioners and manufacturers to increase } \\
\text { reliability and efficiency. }\end{array}$ & MENG, MOPR \\
\hline 4 & & 1.7 & Strengthening Capacity and Capability of Periodic Maintenance. & MHAR \\
\hline \multirow[t]{2}{*}{5} & & 1.8 & Best Practice Preservation Program (mothballed powerplant) & MOPR \\
\hline & \multirow{5}{*}{ SI 03} & Smart & $\begin{array}{c}\text { terprise Asset Management (Stabilize. Improve. Optimise. Sustain and Well } \\
\text { Being) }\end{array}$ & $\begin{array}{l}\text { VP PWG I, II.1 \& } \\
\text { II.2 }\end{array}$ \\
\hline 6 & & 3.1 & Digitalizes Work Planning \& Control & MHAR \\
\hline 7 & & 3.2 & Enhancing Asset Management Culture based on CERIA CULTURE. & MADM \\
\hline 8 & & 3.5 & Improvement of Asset Management Governance. & ATKP \\
\hline 9 & & 3.6 & Increasing the effectiveness of Life Cycle Management (LCM). & MENG \\
\hline
\end{tabular}


2nd International Conference on Industrial and System Engineering (IConISE) and

7th Annual Conference on Industrial and System Engineering (ACISE) 2020

July $22^{\text {nd }}-23^{\text {rd }} 2020$, Surabaya, Indonesia

Appendix A. Strategic initiative table

\begin{tabular}{|c|c|c|c|c|}
\hline No & \multirow[b]{3}{*}{ SI 04} & \multirow{2}{*}{\multicolumn{2}{|c|}{$\begin{array}{l}\text { Strategic Initiatives \& Sub-Strategic Initiatives } \\
\text { Implementation of Excellent Primary Energy Management }\end{array}$}} & \multirow{3}{*}{$\begin{array}{c}\text { PIC } \\
\text { VP PRE I } \\
\text { MOPR }\end{array}$} \\
\hline \multirow[b]{2}{*}{10} & & & & \\
\hline & & 4.3 & $\begin{array}{l}\text { Management of Primary Energy Excellent to increase Generator Efficiency and } \\
\text { Competitiveness. }\end{array}$ & \\
\hline & \multirow{8}{*}{ SI 10} & & Implementasi Roadmap Community \& HSE Excellence & VP HSE \\
\hline 11 & & 10.1 & Program for Compliance and Improved Emission Control. & MOPR \\
\hline 12 & & 10.2 & Environmental PROPER Fulfillment Program. & MOPR \\
\hline 13 & & 10.3 & Hazardous and Non-B3 Waste Management. & MOPR \\
\hline 14 & & 10.4 & $\begin{array}{l}\text { Liquid Waste Compliance Fulfillment Program and Reduction of Liquid Waste } \\
\text { Load. }\end{array}$ & MOPR \\
\hline 15 & & 10.5 & CSMS (Contractor Safety Management System) implementation. & MOPR \\
\hline 16 & & 10.6 & Digitalization of HSS (Health Safety and Security) Business Processes. & MOPR \\
\hline \multirow[t]{2}{*}{17} & & 10.7 & Energy Audit Program and Emission Reduction Efforts. & MOPR,MENG \\
\hline & SI 11 & \multicolumn{2}{|r|}{$\begin{array}{c}\text { Development of Knowledge Management (KM) Processes that Encourage Strategic } \\
\text { Innovation. }\end{array}$} & EVP RIE \\
\hline \multirow[t]{2}{*}{18} & & 11.3 & Innovation Dissemination Program. & MENG \\
\hline & & & Strengthening the Engineering Support Function. & EVP RIE \\
\hline \multirow{2}{*}{19} & \multirow{2}{*}{ SI 12} & 12.4 & TOR Quality Improvement in Supporting the Procurement Process. & MENG \\
\hline & & \multicolumn{2}{|r|}{ Roadmap development and implementation of the digital transformation platform. } & EVP RIE \\
\hline \multirow[t]{2}{*}{20} & \multirow[t]{2}{*}{ SI 14} & 14.3 & Digital Work Culture Transformation. & MADM, MENG \\
\hline & & \multicolumn{2}{|c|}{ Implementation of Learning Value Chain-based Employee Competency Development. } & VP HCD \\
\hline 21 & \multirow{6}{*}{ SI 16} & 16.1 & $\begin{array}{l}\text { Implementation of LNA (Learning Need Analysis) Compilation Based on } \\
\text { Corporate University. }\end{array}$ & MADM \\
\hline 22 & & 16.9 & OME Competency Acceleration in IP Group. & MADM \\
\hline 23 & & 16.12 & Asset Management Capacity Building & MADM, ATKP \\
\hline & & & Increased Expertise Capability for Problem & \\
\hline 24 & & 16.14 & $\begin{array}{l}\text { Solving in Recurring Generating Problems (Chronic) and Business } \\
\text { Development. }\end{array}$ & MADM \\
\hline 25 & & 16.15 & Health Safety and Security Advance Training. & MADM, MOPR \\
\hline
\end{tabular}

